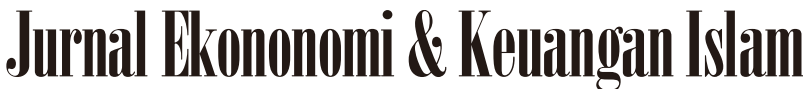

Available at http://journal.uii.ac.id/index.php/jeki

\section{Karakteristik penentu pembiayaan murabahah pada Bank Tabungan Negara (BTN) Syariah}

\author{
Heri susanto*, Eka Dewi Sumarmawati, Nur Kholis \\ Jurusan akuntansi, Sekolah Tinggi Ilmu Ekonomi Surakarta \\ "Corresponding Author, e-mail: herisusanto303@gmail.com
}

Keywords:
Bank, finance, Murabahah,
Bank Tabungan Negara (BTN)
Syariah.

DOI:

10.20885/JEKI.vol2.iss2.art3

\begin{abstract}
This study uses small squares or ordinary least squares (OLS) in an attempt to determine the factors that influence and factors most dominant effect on the financing murabahah in (BTN) Syariah in 2010-2015. The object of this research is to analyze the factors NonPerforming Financing (NPF), Wadiah Certificate of Bank Indonesia (SWBIs) Deposits Third Party Fund (DPK) and Margin Gains effect on murabahah financing in the (BTN) Syariah period of $2010-2015$. The data used in this study was obtained from several sources of activities to obtain the financial statements in the (BTN) Syariah. The results of this study indicate that non-performing financing does not affect the murabahah financing in the (BTN) Syariah, Bank Indonesia Wadiah Certificate significant effect on murabahah financing the (BTN) Syariah, Deposits Deposits no effect on murabahah financing at (BTN) Syariah, significant effect on the Profit margin murabahah financing the (BTN) Syariah financing to Deposit Ratio significant effect on murabahah financing the (BTN) Syariah.
\end{abstract}

\begin{abstract}
Abstrak
Penelitian ini menggunakan kuadrat kecil atau ordinary least squares (OLS) dalam upaya untuk mengetahui faktor-faktor yang mempengaruhi dan faktor-faktor yang paling dominan berpengaruh terhadap pembiayaan murabahah di (BTN) Syariah tahun 2010-2015. Tujuan dari penelitian ini adalah untuk menganalisis faktor-faktor Non-Performing Financing (NPF), Sertifikat Wadiah Simpanan Bank Indonesia (DPK) dan Margin Gain berpengaruh terhadap pembiayaan murabahah pada periode syariah (BTN) tahun 2010-2015. Data yang digunakan dalam penelitian ini diperoleh dari beberapa sumber kegiatan untuk mendapatkan laporan keuangan di (BTN) Syariah. Hasil penelitian ini menunjukkan bahwa pembiayaan bermasalah tidak mempengaruhi pembiayaan murabahah di (BTN) Syariah, Sertifikat Wadiah Bank Indonesia berpengaruh signifikan terhadap pembiayaan murabahah (BTN) Syariah, Deposito Simpanan tidak berpengaruh terhadap pembiayaan murabahah pada (BTN) Syariah, berpengaruh signifikan terhadap Profit Margin murabahah pembiayaan pembiayaan (BTN) Syariah terhadap Rasio Deposito berpengaruh signifikan terhadap pembiayaan murabahah syariah (BTN).
\end{abstract}

\section{Pendahuluan}

Bank syariah memiliki fungsi sebagai perantara jasa keuangan (financial intermediary), yang memiliki tugas pokok yaitu menghimpun dana dari masyarakat dan menyalurkan kembali kepada masyarakat dalam bentuk filsafat pembiayaan. Perbedaan mendasar antara kedua bank tersebut hanyalah bank syariah melakukan kegiatan usahanya tidak berdasarkan bunga (interest fee), namun didasarkan pada prinsip syariah atau prinsip pembagian keutungan dan kerugian (profit and loss sharing principle) (Slamet, 2005). Bank syariah adalah bank umum yang melakukan kegiatan usaha berdasarkan prinsip syariah, termasuk unit usaha syariah dan kantor cabang bank asing yang melakukan kegiatan usaha berdasarkan prinsip syariah (Riyadi, 2005).

Perbankan syariah menjanjikan suatu sistem operasional yang lebih adil khususnya yang ada pada system profit lossharing (bagi hasil) seperti yang ada pada system mudharabah dan sistem musyarakah ini masih tersisihkan, dan yang tentunya muncul ke permukaan adalah produk jual beli 'mark up' seperti murabahah yang tentunya masih juga di khawatirkan publik sebagai upaya yang belum maksimal yang dijalankan oleh perbankan syariah (Wiroso, 2005).

Pembiayaan berdasarkan prinsip syariah adalah penyediaan uang atau tagihan yang dipersamakan dengan itu berdasarkan persetujuan atau kesepakatan antara bank dengan pihak lain yang mewajibkan pihak yang dibiayai untuk mengembalikan uang atau tagihan tersebut setelah jangka waktu tertentu dengan imbalan atau bagi hasil (Kuncoro, 2002).

Tujuan pembiayaan menjadi dua kelompok, yaitu: tujuan pembiayaan untuk tingkat makro (Muhammad, 2005), dan tujuan pembiayaan untuk tingkat mikro. Secara makro, pembiayaan bertujuan untuk: 
1) Peningkatan ekonomi umat. Masyarakat yang tidak dapat akses secara ekonomi,dengan adanya pembiayaan mereka dapat melakukan akses ekonomi. Dengan demikian dapat meningkatkan taraf ekonominya.

2) Tersedianya dana bagi peningkatan usaha. Untuk pengembangan usaha membutuhkan dana. Dana tambahan ini dapat diperoleh dengan melakukan aktivitas pembiayaan. Pihak yang surplus dana menyalurkan kepada pihak minus dana, sehingga dapat tergulirkan.

3) Meningkatkan produktivitas. Pembiayaan memberikan peluang usaha bagi masyarakat agar mampu meningkatkan daya produksinya. Sebab upaya produksi tidak akan dapat jalan tanpa adanya dana.

4) Membuka lapangan kerja baru. Dengan dibukanya sektor-sektor usaha melalui penambahan dana pembiayaan, maka sektor usaha tersebut akan menyerap tenaga kerja. Hal ini berarti menambah atau membuka lapangan kerja baru.

5) Terjadi distribusi pendapatan masyarakat usaha produktif mampu melakukan aktivitas kerja, berarti mereka akan memperoleh pendapatan dari hasil usahanya. Penghasilan merupakan bagian dari pendapatan masyarakat.

Pembiayaan murabahah di Bank Syariah hingga akhir 2014 merupakan prosentase terbesar. Salah satu lembaga bank syariah yang ada di Indonesia adalah Bank Tabungan Negara (BTN) Syariah. BTN Syariah merupakan bank syariah yang memiliki asset cukup besar diantara beberapa bank syariah atau lembaga keuangan syariah lainnya. BTN Syariah adalah lembaga keuangan yang merupakan prinsip bagi hasil dalam menjalankan perannya sebagai lembaga intermediasi keuangan, yaitu lembaga yang memiliki peran sebagai penghimpun dana dari masyarakat dan menyalurkannya kembali ke masyarakat.

Murabahah merupakan salah satu pembiayaan bank syariah yang melalui system jual-beli untuk jasa dengan kesepakatan keuntungan dan jangka waktu tertentu. Mekanisme ini sudah biasa digunakan untuk kebutuhan modal kerja atau sebuah kepemilikan barang dengan cara menyicil. Hubungan para pihak yang tertuang dalam bentuk Akad Pembiayaan murabahah tersebut adalah suatu hubungan hukum yang dapat menimbulkan akibat hukum tertentu.

Murabahah adalah mencerminkan transaksi jual beli harga jual merupakan akumulasi dari biaya-biaya yang telah dikeluarkan untuk mendatangkan objek transaksi atau harga pokok pembelian dengan tambahan keuntungan tertentu yang diinginkan penjual (margin), harga beli dan jumlah keuntungan yang diinginkan diketahui oleh pembeli. Artinya pembeli diberitahu berapa harga belinya dan tambahan keuntungan yang diinginkan.

Murabahah merupakan bagian terpenting dari jual beli dan prinsip akad ini mendominasi pendapatan bank dari produk-produk yang ada di semua bank islam. Dalam Islam, jual beli sebagai sarana tolong menolong antara sesama umat manusia yang diridhai oleh Allah SWT. "Allah telah menghalalkan jual beli dan mengharamkan riba" (QS. Al-baqarah: 275) (Wiroso,2005)

Di samping itu, perhitungan-perhitungan dalam produk mudharabah (sistem bagi hasil) lebih rumit bila dibandingkan perhitungan dalam bank konvensional, sehingga dibutuhkan tenaga profesional yang sangat handal. Padahal, selama ini kebanyakan tenaga profesional yang dimiliki bank syari'ah diambil dari bank konvensional yang masih terkonstruk perhitungan dengan sistem bunga (Muhammad, 2004).

\section{NPF (Non-Performing Financing)}

NPF (Non-Performing Financing) merupakan suatu keadaan dimana nasabah sudah tidak sanggup lagi membayar sebagian atau seluruh kewajiban kepada bank seperti yang telah diperjanjikannya (Kuncoro, 2002). Jika tidak ditangani dengan baik, maka pembiayaan bermasalah merupakan sumber kerugian yang sangat potensial bagi bank. Karena itu diperlukan penanganan yang sistematis dan berkelanjutan (Mahmoedin, 2010).

Semakin ketat kebijakan kredit/analisis pembiayaan yang dilakukan bank (semakin ditekan tingkat NPF) akan menyebabkan tingkat permintaan pembiayaan oleh masyarakat turun. NPF (Non-Performing Financing) yaitu untuk mengukur tingkat permasalahan pembiayaan yang dihadapi oleh bank. Semakin tinggi rasio ini, menunjukkan bahwa kualitas pembiayaan semakin tidak sehat (Mahmoeddin, 2004).

Berdasarkan uraian di atas, maka dapat dirumuskan hipotesis penelitian bahwa Non-Performing Financing diduga berpengaruh terhadap pembiayaan murabahah pada Bank Tabungan Negara (BTN) Syariah.

\section{Sertifikat wadiah bank Indonesia (SWBI)}

Sertifikat wadiah bank Indonesia (SWBI) merupakan salah satu alat untuk penyerapan kelebihan likuiditas yang dialami oleh perbankan syariah. SWBI adalah surat berharga berdasarkan prinsip syariahberjangka pendek dalam mata uang rupiah yang diterbitkan oleh Bank Indonesia. Bank Indonesia menetapkan dan memberikan imbalan atas SWBI yang diterbitkan yang dibayarkan pada saat jatuh tempo.

Pihak yang dapat memiliki SWBI adalah Bank Umum Syariah dan Unit Usaha Syariah. Karakteristik SWBIsebagaimana diterangkan dalam pasal 6 peraturan BI tahun 2004 adalah, SWBI diterbitkan dan 
ditatausahakan tanpa warkat, SWBI tidak dapat diperjualbelikan, benefit yang diberikan dari SWBI bukan bunga tetapi sistem diskonto. Fungsi SWBI secara tidak langsung menyebabkan naik turunnya tingkat suku bunga SBI dan berdampak juga terhadap perkembangan perbankan syariah (Nurapriyani, 2009).

Berdasarkan uraian di atas, maka dapat dirumuskan hipotesis penelitian Sertifikat Wadiah Bank Indonesia diduga berpengaruh terhadap pembiayaan murabahah pada Bank Tabungan Negara (BTN) Syariah.

\section{Dana Pihak Ketiga (DPK)}

Dana Pihak Ketiga (DPK) merupakan dana simpanan dari masyarakat yang dititipkan kepada bank syariah, yang penarikannya dapat dilakukan setiap saat tanpa pemberitahuan terlebih dahulu kepada bank dengan media penarikan tertentu. Dana yang dihimpun dari masyarakat merupakan sumber dana terbesar yang diandalkan oleh bank (mencapai 80\%-90\%). Dana simpanan pada bank syariah juga sedapat mungkin mampu dimanfaatkan oleh bank untuk kegiatan operasional bank syariah. Dana simpanan dari masyarakat bisa berupa: giro, deposito, dan tabungan (Dendawijaya, 2009).

Berdasarkan uraian di atas, maka dapat dirumuskan hipotesis penelitian bahwa Simpanan Dana Pihak Ketiga diduga berpengaruh terhadap pembiayaan murabahah pada Bank Tabungan Negara (BTN) Syariah.

\section{Profit margin}

Selain dari besarnya pembiayaan murabahah, besarnya pendapatan yang diperoleh dari pembiayaan murabahah akan sangat berkaitan dengan besarnya tingkat margin murabahah yang dibebankan bank syariah kepada nasabah pembiayaan. Margin murabahah menurut Kamaen (2009) yaitu selisih antara harga jual dikurangi dengan harga beli.

Bank syariah menerapkan marjin keuntungan terhadap produk-produk pembiayaan yang berbasis NCC (Natural Cer tainty Contract), yakni akad bisnis yang memberikan kepastian pembayaran, baik dari segi jumlah maupun waktu, seperti pembiayaan murabahah, ijarah, muntahia bit tamlik, salam, dan istishna.

Berdasarkan uraian di atas, maka dapat dirumuskan hipotesis penelitian margin Keuntungan diduga berpengaruh terhadap pembiayaan murabahah pada Bank Tabungan Negara (BTN) Syariah.

\section{Financing to Deposit Ratio}

Financing to Deposit Ratio (FDR) adalah rasio antara jumlah pembiayaan yang diberikan bank dengan dana yang diterima oleh bank (Surya, 2008). FDR ditentukan oleh perbandingan antara jumlah pinjaman yang diberikan dengan dana masyarakat yang dihimpun yaitu mencakup tabungan, giro, dan deposito. Financing to Deposit Ratio (FDR) tersebut menyatakan seberapa jauh kemampuan bank dalam membayar kembali penarikan dana yang dilakukan deposan dengan mengandalkan kredit yang diberikan sebagai sumber likuiditasnya. Semakin besar kredit maka pendapatan yang diperoleh naik, karena pendapatan naik secara otomatis laba juga akan mengalami kenaikan.

Bank dikatakan Likuid apabila bank yang bersangkutan dapat memenuhi kewajiban utang-utangnya, dapat membayar kembali semua deposannya, serta dapat memenuhi semua permintaan pembiayaan/kredit yang diajukan tanpa terjadi penangguhan. Perangkat yang digunakan oleh bank syariah untuk memenuhi likuiditasnya antara lain: surat berharga pasar modal, pasar uang antar bank syariah (PUAS), SBIS, dan Islamic Interbank Money (Arifin, 2002). Semakin besar kredit maka pendapatan yang diperoleh naik, karena pendapatan naik secara otomatis laba juga akan mengalami kenaikan.

Berdasarkan uraian di atas, maka dapat dirumuskan hipotesis penelitian financing to Deposit Ratio diduga berpengaruh terhadap pembiayaan murabahah pada Bank Tabungan Negara (BTN) Syariah.

\section{Metode Penelitian}

Populasi penelitian ini adalah laporan keuangan Ban BTN Syariah. Sampel dalam penelitian ini adalah laporan keuangan Bank BTN Syariah tahun 2012-2015. Sampel penelitian ini diperoleh menggunakan purposive sampling. Dengan kriteria laporan keuangan diterbitkan dan dapat diakses secara umum. Variabel dependen yang digunakan dalam penelitian ini yaitu pembiayaan murabahah (MRB). Variabel independen dalam penelitian ini terdiri dari 5 variabel yang dikategorikan dalam 5 karakteristik diantaranya, NPL, SWBD, DPK, Profit margin dan FDR.

Alat analisis digunakan untuk mengetahui besarnya pengaruh dari suatu variabel bebas (independen) terhadap variabel terikat (dependen). Maka penelitian ini menggunakan metode kuadrat kecil atau ordinary least square (OLS) (Ghozali, 2011). Pengolahan data menggunakan program SPSS. Adapun model ekonometrik adalah sebagai berikut: 


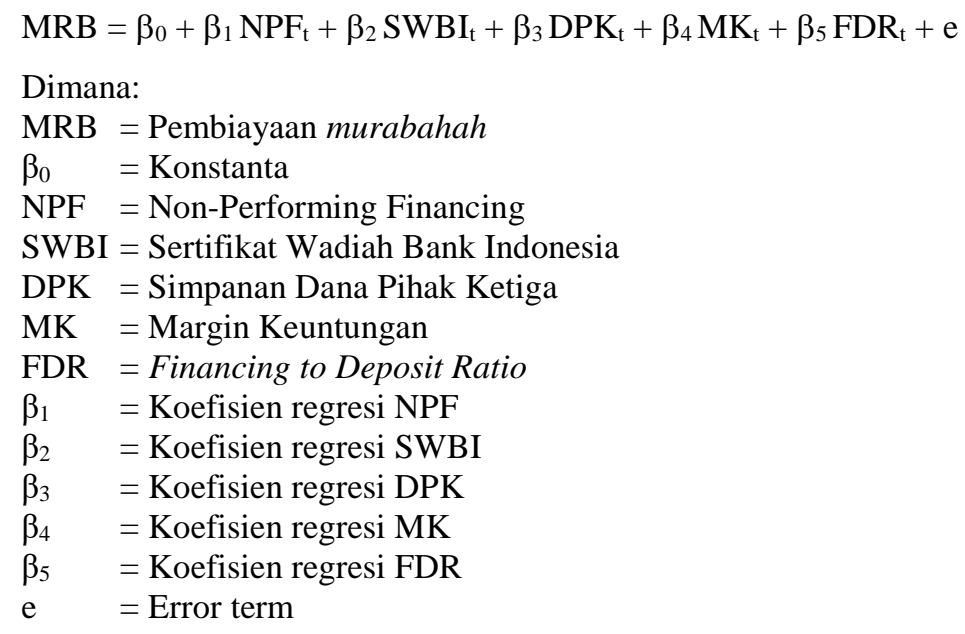

Pengujian hipotesis dalam penelitian ini dilakukan denggan uji t, uji $\mathrm{F}$ dan koefisien determinasi $\left(\mathrm{R}^{2}\right)$

\section{Hasil Penelitian dan Pembahasan}

Deskripsi statistik data penelitian adalah sebagai berikut:

Tabel 1. Descriptive Statistics

\begin{tabular}{lcrrrr}
\hline & N & \multicolumn{1}{c}{ Minimum } & \multicolumn{1}{c}{ Maximum } & \multicolumn{1}{c}{ Mean } & \multicolumn{1}{c}{ Std. Deviation } \\
\hline X1 & 12 & .108 & .252 & .17533 & .037095 \\
X2 & 12 & 190646.00 & 2198589.00 & 979989.0833 & 653930.56514 \\
X3 & 12 & 1525284.00 & 8905947.00 & 5017088.4167 & 2387072.32170 \\
X4 & 12 & 76470.00 & 1111183.00 & 423034.8333 & 320979.28829 \\
X5 & 12 & .421 & .741 & .59392 & .099585 \\
Y & 12 & 1121466.00 & 3970180.00 & 2814396.0000 & 1063275.58868 \\
\hline Valid N & 12 & & & & \\
(listwise) & 12 & & & & \\
\hline
\end{tabular}

Hasil perhitungan diketahui bahwa nilai Non-Performing Financing (NPF) terendah adalah 0,108 dan nilai tertinggi adalah 0,252 dengan standar deviasi sebesar 0,037. Nilai rata-rata Non Performing Financing $(N P F)$ pada Bank Tabung Negara (BTN) Syariah tahun 2010-2015 adalah 0,175; hal ini menunjukkan bahwa terdapat $17,5 \%$ pembiayaan yang nasabah sudah tidak sanggup lagi membayar sebagian atau seluruh kewajiban kepada bank seperti yang telah diperjanjikannya. Hasil perhitungan diketahui bahwa nilai $S W B I$ terendah adalah 190.646,00 dan nilai tertinggi adalah 2.198.589,00 dengan standar deviasi sebesar 653.930,565. Nilai rata-rata SWBI pada Bank Tabung Negara (BTN) Syariah tahun 2010-2015 adalah 979.989,083; hal ini menunjukkan bahwa besarnya alat untuk penyerapan kelebihan likuiditas yang dialami oleh bank adalah 979.989,083.

Hasil perhitungan diketahui bahwa nilai DPK terendah adalah 1.525.284,00 dan nilai tertinggi adalah 8.905.947,00 dengan standar deviasi sebesar 2.387.072,321. Nilai rata-rata DPK pada Bank Tabung Negara (BTN) Syariah tahun 2010-2015 adalah 5.017.088,416, hal ini menunjukkan bahwa dana yang berasal dari masyarakat, perorangan maupun badan usaha yang diperoleh bank adalah 5.017.088,416.

Hasil perhitungan diketahui bahwa nilai margin keuntungan terendah adalah $76.470,00$ dan nilai tertinggi adalah 1.111.183,00 dengan standar deviasi sebesar 320.979,288. Nilai rata-rata margin keuntungan pada Bank Tabung Negara (BTN) Syariah tahun 2010-2015 adalah 423.034,833, hal ini menunjukkan bahwa kenaikan kotor dalam asset atau penurunan dalam liabilitas atau gabungan dari keduanya selama periode 2010 2015 adalah 423.034,833. Hasil perhitungan diketahui bahwa nilai FDR terendah adalah 0,421 dan nilai tertinggi adalah 0,741 dengan standar deviasi sebesar 0,099. Nilai rata-rata FDR pada Bank Tabung Negara (BTN) Syariah tahun 2010-2015 adalah 0,893, hal ini menunjukkan bahwa jumlah pembiayaan yang diberikan bank dengan dana yang diterima oleh bank adalah 59,3\%.

Berdasarkan hasil perhitungan diketahui bahwa nilai pembiayaan murabahah terendah adalah 1.121.466,00 dan nilai tertinggi adalah 3.970.180,00 dengan standar deviasi sebesar 1.063.275,588. Nilai ratarata pembiayaan murabahah pada Bank Tabung Negara (BTN) Syariah tahun 2010-2015 adalah 2.814.396,00, hal ini menunjukkan bahwa rata-rata pembiayaan murabahah adalah 2.814.396,00. 
Analisis regresi berganda bertujuan mengetahui karakteristik yang mempengaruhi pembiayaan murabahah pada Bank Tabungan Negara (BTN) Syariah. Adapun berdasarkan perhitungan diperoleh hasil sebagai berikut:

Tabel 2. Hasil Pengujian Regresi Linier Berganda

\begin{tabular}{|c|c|c|c|c|}
\hline Variabel & Coefficient & Beta & $\mathbf{t}_{\text {hitung }}$ & $p$ \\
\hline (Constant) & $-4638911,227$ & & $-3,369$ & 0,015 \\
\hline NPF & 400468,704 & 0,014 & $-0,104$ & 0,920 \\
\hline SWBI & $-1,465$ & $-0,901$ & 2,098 & 0,081 \\
\hline DPK & 0,994 & 2,232 & 5,827 & 0,001 \\
\hline MK & 0,058 & 0,018 & 0,126 & 0,904 \\
\hline FDR & 6409828,116 & 0,600 & 5,074 & 0,002 \\
\hline \multicolumn{5}{|l|}{ Adj. $R^{2}=0,982$} \\
\hline$F_{\text {hitung }}=63,902$ & & & & \\
\hline $\mathrm{F}_{\text {tabel }}=2,24$ & & & & \\
\hline $\mathrm{t}_{\text {tabel }}=1,671$ & & & & \\
\hline
\end{tabular}

Sumber: data primer diolah

Dari Tabel yang merupakan hasil pengujian regresi linier berganda dapat dibuat persamaan regresi sebagai berikut:

$Y=-4638911,227+400468,704 X_{1}-1,465 X_{2}+0,994 X_{3}+0,058 X_{4}+6409828,116 X_{5}+e$

Hasil perhitungan menunjukkan bahwa Dana Pihak Ketiga diperoleh nilai koefieisen beta sebesar 2,232 yang lebih besar jika dibandingkan dengan variabel yang lainnya. Hal ini menunjukkan bahwa Dana Pihak Ketiga paling dominan berpengaruh terhadap pembiayaan murabahah pada Bank Tabungan Negara (BTN) Syariah.

Berdasarkan hasil penelitian tentang faktor-faktor yang mempengaruhi pembiayaan murabahah di Bank Tabungan Negara (BTN) Syariah pada tahun 2010-2015 diperoleh hasil sebagai berikut:

\section{Pengaruh Non-Performing Financing terhadap Pembiayaan Murabahah pada Bank Tabungan Negara (BTN) Syariah}

Pengaruh non performing financing terhadap pembiayaan murabahah pada Bank Tabungan Negara (BTN)

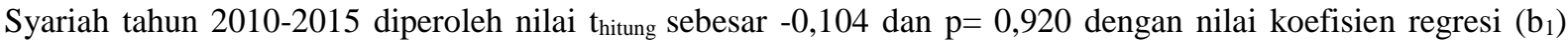
sebesar 4004681,704 dengan parameter positif; hal ini menunjukkan bahwa setiap terjadi peningkatan non performing financing sebesar 1\%, maka akan meningkatkan pembiayaan murabahah pada Bank Tabungan Negara (BTN) Syariah sebesar 4004681,704 dengan asumsi variabel yang lain konstan. Oleh karena nilai $t_{\text {hitung }}$ lebih kecil dari $\mathrm{t}_{\text {tabel }}(0,104<1,671)$ dan $\mathrm{p}=0,920>0,05 ;$ maka $\mathrm{H}_{1}$ ditolak, yang berarti bahwa non performing financing tidak berpengaruh terhadap pembiayaan murabahah pada Bank Tabungan Negara (BTN) Syariah.

NPF (Non Performing Financing) merupakan suatu keadaan dimana nasabah sudah tidak sanggup lagi membayar sebagian atau seluruh kewajiban kepada bank seperti yang telah diperjanjikannya (Kuncoro, 2002). NPF (Non Performing Financing) sangat berpengaruh dalam pengendalian biaya dan sekaligus juga berpengaruh terhadap kebijakan pembiayaan yang akan dilakukan bank itu sendiri. NPF (Non Performing Financing) dapat mendatangkan dampak yang tidak menguntungkan, terlebih lagi bila NPF (Non Performing Financing) tersebut dalam jumlah besar. Dengan melihat NPF sebelumnya, bank dapat mempertimbangkan berapa besar pembiayaan yang akan disalurkan sekarang. Sehingga semakin tinggi NPF maka semakin buruk kualitas aktiva produktif bank tersebut yang akan mempengaruhi biaya dan permodalan bank tersebut karena dengan NPF yang tinggi akan membuat bank mempunyai kewajiban dan harus mengeluarkan biaya untuk memenuhi PPAP (Penyisihan Penghapusan Aktiva Produktif) yang terbentuk. Bila ini terus menerus terjadi maka modal bank akan tersendot untuk PPAP sehingga menurunkan nilai profitabilitas bank.

\section{Pengaruh Sertifikat Wadiah Bank Indonesia terhadap Pembiayaan Murabahah pada Bank Tabungan Negara (BTN) Syariah \\ Pengaruh Sertifikat Wadiah Bank Indonesia terhadap pembiayaan murabahah pada Bank Tabungan Negara (BTN) Syariah tahun 2010-2015 diperoleh nilai $t_{\text {hitung }}$ sebesar -2,098 dan $\mathrm{p}=$ 0,081 dengan nilai koefisien regresi $\left(b_{2}\right)$ sebesar -1,465 dengan parameter negatif; hal ini menunjukkan bahwa setiap terjadi peningkatan Sertifikat Wadiah Bank Indonesia sebesar 1 rupiah, maka akan menurunkan pembiayaan murabahah pada Bank Tabungan}


Negara (BTN) Syariah sebesar 1,465 rupiah dengan asumsi variabel yang lain konstan. Oleh karena nilai $t_{\text {hitung }}$ lebih kecil dari tabel $(-2,098<1,671)$ dan $\mathrm{p}=0,081>0,05$; maka $\mathrm{H}_{2}$ ditolak, yang berarti bahwa Sertifikat Wadiah Bank Indonesia tidak berpengaruh terhadap pembiayaan murabahah pada Bank Tabungan Negara (BTN) Syariah.

Sertifikat wadiah bank Indonesia $(S W B I)$ merupakan salah satu alat untuk penyerapan kelebihan likuiditas yang dialami oleh perbankan syariah. SWBI adalah surat berharga berdasarkan prinsip syariah berjangka pendek dalam mata uang rupiah yang diterbitkan oleh Bank Indonesia. Bank Indonesia menetapkan dan memberikan imbalan atas SWBI yang diterbitkan yang dibayarkan pada saat jatuh tempo. Pihak yang dapat memiliki SWBI adalah Bank Umum Syariah dan Unit Usaha Syariah. Karakteristik SWBI sebagaimana diterangkan dalam pasal 6 peraturan BI tahun 2004 adalah, SWBI diterbitkan dan ditatausahakan tanpa warkat, SWBI tidak dapat diperjualbelikan, benefit yang diberikan dari SWBI bukan bunga tetapi sistem diskonto. Fungsi SWBI secara tidak langsung menyebabkan naik turunnya tingkat suku bunga SBI dan berdampak juga terhadap perkembangan perbankan syariah (Nurapriyani, 2009).

\section{Pengaruh Simpanan Dana Pihak Ketiga terhadap Pembiayaan Murabahah pada Bank Tabungan Negara (BTN) Syariah}

Pengaruh Simpanan Dana Pihak Ketiga terhadap pembiayaan murabahah pada Bank Tabungan Negara (BTN) Syariah tahun 2010-2015 diperoleh nilai $t_{\text {hitung }}$ sebesar 5,827 dan $\mathrm{p}=0$,001 dengan nilai koefisien regresi $\left(\mathrm{b}_{3}\right)$ sebesar 0,994 dengan parameter positif; hal ini menunjukkan bahwa setiap terjadi peningkatan Simpanan Dana Pihak Ketiga sebesar 1 rupiah, maka akan menurunkan pembiayaan murabahah pada Bank Tabungan Negara (BTN) Syariah sebesar 0,994 rupiah dengan asumsi variabel yang lain konstan. Oleh karena nilai $t_{\text {hitung }}$ lebih besar dari $t_{\text {tabel }}$ $(5,827>1,671)$ dan $\mathrm{p}=0,001<0,05 ;$ maka $\mathrm{H}_{3}$ diterima, yang berarti bahwa Simpanan Dana Pihak Ketiga berpengaruh signifikan terhadap pembiayaan murabahah pada Bank Tabungan Negara (BTN) Syariah.

Simpanan Dana Pihak Ketiga (DPK) merupakan dana simpanan dari masyarakat yang dititipkan kepada bank syariah, yang penarikannya dapat dilakukan setiap saat tanpa pemberitahuan terlebih dahulu kepada bank dengan media penarikan tertentu. Dana yang dihimpun dari masyarakat merupakan sumber dana terbesar yang diandalkan oleh bank (mencapai 80\%-90\%). Dana simpanan pada bank syariah juga sedapat mungkin mampu dimanfaatkan oleh bank untuk kegiatan operasional bank syariah. Dana simpanan dari masyarakat bisa berupa: giro, deposito, dan tabungan (Dendawijaya, 2009).

\section{Pengaruh Margin Keuntungan terhadap Pembiayaan Murabahah pada Bank Tabungan Negara (BTN) Syariah}

Pengaruh Margin Keuntungan terhadap pembiayaan murabahah pada Bank Tabungan Negara (BTN) Syariah tahun 2010-2015 diperoleh nilai $t_{\text {hitung }}$ sebesar 0,126 dan $\mathrm{p}=0,904$ dengan nilai koefisien regresi $\left(\mathrm{b}_{4}\right)$ sebesar 0,058 dengan parameter positif; hal ini menunjukkan bahwa setiap terjadi peningkatan Margin Keuntungan sebesar 1 rupiah, maka akan meningkatkan pembiayaan murabahah pada Bank Tabungan Negara (BTN) Syariah sebesar 0,058 rupiah dengan asumsi variabel yang lain konstan. Oleh karena nilai $t_{\text {hitung }}$ lebih kecil dari tabel $(0,126<1,671)$ dan $\mathrm{p}=0,904>0,05$; maka $\mathrm{H}_{4}$ ditolak, yang berarti bahwa Margin Keuntungan tidak berpengaruh terhadap pembiayaan murabahah pada Bank Tabungan Negara (BTN) Syariah.

Pendapatan yang diperoleh dari pembiayaan dengan prinsip jual beli disebut pendapatan margin. Dengan demikian, pendapatan dari pembiayaan murabahah disebut sebagai pendapatan margin murabahah. Selain dari besarnya pembiayaan murabahah, besarnya pendapatan yang diperoleh dari pembiayaan murabahah akan sangat berkaitan dengan besarnya tingkat margin murabahah yang dibebankan bank syariah kepada nasabah pembiayaan. Margin murabahah menurut Perwata Atmadja (2009) yaitu selisih antara harga jual dikurangi dengan harga beli. Bank syariah menerapkan marjin keuntungan terhadap produk-produk pembiayaan yang berbasis NCC (Natural Cer tainty Contract), yakni akad bisnis yang memberikan kepastian pembayaran, baik dari segi jumlah maupun waktu, seperti pembiayaan murabahah, ijarah, muntahia bit tamlik, salam, dan istishna.

\section{Pengaruh Financing to Deposit Ratio terhadap Pembiayaan Murabahah pada Bank Tabungan Negara (BTN) Syariah}

Pengaruh Financing to Deposit Ratio terhadap pembiayaan murabahah pada Bank Tabungan Negara (BTN) Syariah tahun 2010-2015 diperoleh nilai thitung sebesar 5,074 dan $\mathrm{p}=0,002$ dengan nilai koefisien regresi $\left(\mathrm{b}_{5}\right)$ sebesar 6409828,116 dengan parameter positif; hal ini menunjukkan bahwa setiap terjadi peningkatan Financing to Deposit Ratio sebesar 1\%, maka akan meningkatkan pembiayaan murabahah pada Bank Tabungan Negara (BTN) Syariah sebesar 6409828,116 rupiah dengan asumsi variabel yang lain konstan. Oleh karena nilai thitung lebih besar dari tabel $(5,074>1,671)$ dan $\mathrm{p}=0,002<0,05 ;$ maka $\mathrm{H}_{5}$ diterima, yang berarti bahwa Financing to Deposit Ratio berpengaruh signifikan terhadap pembiayaan murabahah pada Bank Tabungan Negara (BTN) Syariah. 
Financing to Deposit Ratio (FDR) adalah rasio antara jumlah pembiayaan yang diberikan bank dengan dana yang diterima oleh bank (Surya, 2008). Financing to Deposit Ratio (FDR) tersebut menyatakan seberapa jauh kemampuan bank dalam membayar kembali penarikan dana yang dilakukan deposan dengan mengandalkan kredit yang diberikan sebagai sumber likuiditasnya. Semakin besar kredit maka pendapatan yang diperoleh naik, karena pendapatan naik secara otomatis laba juga akan mengalami kenaikan.

\section{Kesimpulan}

Penelitian ini menguji karakteristik yang berpengaruh terhadap pembiayaan murabahah pada bank BTN syariah. Simpulan yang diperoleh bahwa simpanan dana pihak ketida dan FDR (financial deposite ratio) berpengaruh terhadap pembiayaan murabahah. Karakteristik lainnya yang diuji tidak memiliki pengaruh. Hal ini menunjukkan bahwa setiap terjadi peningkatan simpanan dana pihak ketiga dan Financing to Deposit Ratio, maka akan meningkatkan pembiayaan murabahah pada Bank Tabungan Negara (BTN) Syariah. Bertolak pada hasil penelitian di atas, maka penulis memberikan saran pada penelitian selanjutnya agar lebih fokus hasil penelitiannya, gunakan salah satu jenis pembiayaan syariah yang ada seperti murabahah atau ijarah atau mudharabah/musyarakah sebagai variabel terikat (dependen). Untuk manajemen bank, penggalian/pengumpulan DPK diusahakan semaksimal mungkin. Berbagai inovasi terus dimunculkan, sosialisasi digiatkan, dan berbagai strategi pengumpulan dana pihak ketiga yang efektif dan sesuai syariah dijalankan.

\section{Daftar Pustaka}

Arifin, Zainul. 2002. Dasar-Dasar Manajemen Bank Syariah. Jakarta: Alfabeta.

Dendawijaya, Lukman. 2009. Manajemen Perbankan. Jakarta: Ghalia Indonesia.

Ghozali, Imam, 2011. Aplikasi Analisis Multivariate Dengan Program SPSS, Cetakan IV, Badan penerbit Universitas Diponegoro, Semarang.

Jihad dan M. Nadratauz Zaman Hosen. (2009). Faktor-Faktor yang Mempengaruhi Permintaan Pembiayaan Murabahah Bank Syariah di Indonesia (Periode Januari 2004-Desember 2008). Dikta Ekonomi. Volume 6 Nomor 2, Agustus 09.

Hoessein, Muhammad. (2004). Permasalahan Hukum dan Penyelesaian Sengketa dalam Akad Keuangan Syariah, (dalam kutipan seminar).

Kuncoro, Mudrajad, (2002), Manajemen Perbankan (Teori dan Aplikasi). Edisi Pertama. Yogyakarta: BPFE.

Muhammad. (2005). Manajemen Bank Syariah, UPP AMP YKPN: Yogyakarta.

Mahmoeddin. (2010). Melacak Kredit Bermasalah, Jakarta: Pustaka Sinar Harapan.

Munawir, 2007, Analisa Laporan Keuangan. Liberty, Yogyakarta.

Mustika Rimadhani dan Osni Erza. (2011) Analisis Variabel-Variabel yang Mempengaruhi Pembiayaan Murabahah pada Bank Syariah Mandiri Periode 2008.01-2011.12. Media Ekonomi Vol. 19, No. 1, April 2011.

Nurapriyani, Dwi. 2009. Faktor-Faktor yang Mempengaruhi Pembiayaan Murbahah di Bank Syariah Mandiri Periode Tahun 2004-2007. Jurnal Ekonomi. Universitas Negeri Sunan Kalijaga Yogayakarta.

Kamaen, Perwaatmadja, 2009. Prinsip Operasional Bank Syariah, Jakarta: Risalah Masa

Riyadi, Selamet, (2005), Banking Assets and Liability Management, Edisi Ketiga, Jakarta: Lembaga Penerbit Fakultas Ekonomi Universitas Indonesia.

Santoso, Singgih. 2003. SPSS Statistik Multivariat. PT. Elex Media Komputindo. Jakarta.

Slamet, Dahlan, (2005), Manajemen Lembaga Keuangan, Jakarta: Intermedia.

Sutan, Remy Sjahdeini, (2002), Perbankan Islam dan Kedudukannya dalam Tata Hukum Perbankan Indonesia, Jakarta: Pustaka Utama Grafiti.

Surya, Andi. 2008. Pengaruh Dana Pihak Ketiga (DPK), Non Performing Financing (NPF), Financing to Deposit Ratio (FDR), dan Pendapatan Terhadap Pembiayaan Bagi Hasil di Bank Muamalat. SKRIPSI.

Wiroso SE.MBA. (2005). Jual Beli Murabahah, Yogyakarta: UII Press.

Wiroso, (2005), Penghimpun Dana dan Distribusi Hasil Usaha Bank Syariah, Jakarta: PT. Grasindo. 